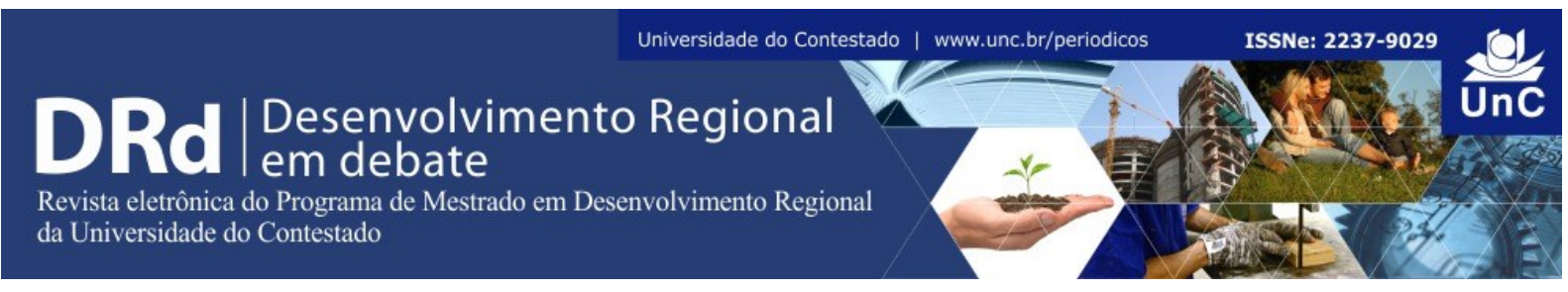

\title{
TERRITORY, GEOGRAPHICAL INDICATION AND TERRITORIAL DEVELOPMENT ${ }^{1}$
}

Marcos Aurelio Saquet ${ }^{2}$

\begin{abstract}
RESUMO
Neste artigo, socializamos algumas reflexões que fizemos nos últimos quinze anos sobre a relação território-desenvolvimento, considerando algumas obras clássicas e outras mais recentes, de autores estrangeiros e brasileiros. Tentamos produzir uma síntese que possa servir de orientação teórico-conceitual para quem trabalha essa temática, como fundamentação para pesquisas e para nossa atuação em projetos e processos de desenvolvimento territorial de base local e ecológica. Trabalhamos, portanto, na interface entre pesquisa e extensão, por nós denominada de cooperação voltada para o desenvolvimento, no caso específico deste texto, a ser construído em processos de institucionalização da indicação geográfica a partir do patrimônio de cada território e da autonomia decisória.
\end{abstract}

Palavras-chave: Território. Desenvolvimento. Indicação geográfica. Patrimônio.

\section{TERRITÓRIO, INDICAÇÃO GEOGRÁFICA E DESENVOLVIMENTO TERRITORIAL}

\begin{abstract}
In this article, we socialize some reflections we have made the last fifteen years on the territory-development relationship, considering some classic and more recent works of foreign and Brazilian authors. We try to produce a synthesis that can serve as a theoretical and conceptual guidance for those working with this theme, as the basis for research and for our work on projects and territorial development processes of local and ecological basis. Therefore, we work the interface between research and extension, called by us as cooperation focused on development, in the specific case of this text, to be built in institutionalization processes of geographical indication from the heritage of each territory and the decisionmaking autonomy.
\end{abstract}

Keywords: Territory. Development. Geographical indication. Heritage.

\footnotetext{
${ }^{1}$ Tradução: Oscar Garcia.

${ }^{2}$ UNIOESTE. (Francisco Beltrão-PR) Group Coordinator of Territorial Studies (GETERR). CNPq researcher. Mail: saquetmarcos@hotmail.com
} 
To recognize and recover the biocultural memory of mankind is an essential task, necessary, urgent and mandatory. This will allow the visualization, construction and implementation of an alternative modernity, a modernity that does not destroy tradition, but that coexists, cooperates and coevolves with it. (Toledo and BarreraBassols, 2015 [2008], p. 257).

\section{INTRODUCTION AND CONTEXTUALIZATION}

In the late twentieth and early twenty-first century, we have lived through profound changes at international level, in society in general, in space, in time and in Science. In Geography, in constant attempts to understand the reality, with ruptures and continuities, among other aspects, there was the expansion of the use of the territory concept, often indiscriminately with the necessary academic and scientific care without neglecting popular knowledge and other important concepts, such as time, space, location, region and landscape. As it is already known, there is a fad that devalues the production of knowledge and trivializes concepts; however, at the same time, there are qualified debates, both in Brazil and abroad, in countries such as France, England, Italy, Switzerland, among others.

Why is the spread of the territory concept occurring? The answer, evidently, is neither simple nor restricted; however, we think it is important to mention that over the last 20 years we have realized certain identification of many people with this concept in Brazil, with its plural meanings that lead us to broader and hybrid approaches. There are different possibilities of use in the study of reality, sometimes highlighting cultural processes, sometimes political, economic processes and even environmental and/or natural. And this is a very important reason, because its use is spread in different areas of knowledge precisely because of that: it can serve as a guide for very different topics of study and at the same time, interdisciplinary, in line with the complexity of reality.

There are different approaches and historical-critical concepts of territory, each one with its scientific contribution. Territory is thus understood as a concept of guidance and interpretation and/or as an object of study and/or as mobilization, struggle and political and cultural resistance space. Therefore, it is easy to see different possibilities for its use inside and outside schools, among them, of course, Universities, in teaching, research and extension/cooperation focused on territorial development.

In Brazil, the territory concept use, in perspectives considered renewed, assumes greater intensity from the early 1990s, as already evidenced in previous works such as Saquet (2004, 2005, 2007, 2009, 2011a, 2011b, 2013 , 2014a and 2014b) as well as other researchers have shown, such as Heidrich (2010) and Fuini (2014). There are important previous publications, such as Andrade (1971 [1967]), Goldenstein and Seabra (1982), Becker (1983) and Santos (1988); however, the dissemination really occurs from the last decade of the twentieth century.

At international level, the systematic use of territory in historical-critical conceptions is earlier, it occurs from the years 1950-60, depending on the thematic focus we perform. We have already highlighted works of Gottmann (1947, 1952 and 1973), Dematteis (1964 and 1970), Quaini (1973, 1974a and 1974b), Magnaghi (1976), Bagnasco (1977 and 1978), 
Raffestin (1977 and 1993 [1980]), Deleuze and Guattari (1976 [1972]), Indovina and Calabi (1974), among others. This time, we have selected some more directly linked to the development issue, such as Becattini (2000 [1979] and 2000 [1989]), Bagnasco (1977 and 1988), Dematteis (1989, 1994 and 2001), Raffestin (1993 [1980] and 2005) and Magnaghi (2000, 2003, 2006a and 2006b).

We have chosen these five reference authors showing some of their basic works, due to their scientific education areas, pioneering an international level, because they are considered classic in the debate on territorial development and because of the consistency of their approaches, though they are partially different. Hereby, we aim to resume and enhance explanatory arguments that can be adapted to other historical and geographical contexts, once the social and natural singularities of each space-time relationship are considered. To do this, we basically made the literature research, readings, book reports (summaries), analytical comparisons and some reflections from the concrete reality of Southwest Paraná, where the peasant customs are still very present.

Briefly, from Becattini (2000 [1979]), we highlight the understanding of the industrial district corresponding to: a territorial reality where there are subjects that maintain social relationships, technologies, infrastructure, networks, ideologies and a historically constructed identity; a set of social and natural elements, locally defined, with businesses, families, churches, schools and political parties; a socio-territorial reality that cannot be reproduced in other contexts!

Now, according to Becattini (2000 [1989]), in a more updated conception, the industrial district has the following characteristics: it involves a community of people and a group of companies that influence each other, forming networks between suppliers and consumers; there is a local network of specialized transactions in certain products linked to global networks, in an empowerment process of local and specific features, like with typical products valuing also the local community and the bonds historically played! There is, therein, in the author's words, a strong sense of belonging to the local community, concentration, specialization and dispersion, as well as coexistence of competition and cooperation.

From Bagnasco (1977), in turn, it is important to highlight the plurality of his conception of regional development, understood as a territorial issue. Therefore, he highlights the economic, political and cultural processes; the territorial joints; the changes and continuities. The Italian industrial districts are formed by local production systems, resulting from the State, market, social classes and local identities intervention. It is a complex phenomenon articulated to the international division of labor, they are scattered in the territory and are formed by small and medium enterprises substantiating a heterogeneous and plural reality.

In a later work, Bagnasco (1988) updated and completed this understanding, highlighting four mechanisms of economic regulation present in development territorialization: a) the existing reciprocity among individuals and/or institutions; b) the market, relationships and social activities maker; c) the organization, internal and external, of each company and; d) the policy, as an intervention in favor of certain social groups' interests. In this processuality, there are also links, traditions, trust relationships, recognition and identity among similar companies dependent on each other; domination, dispersed and articulated systems; specific ways of producing (typical products). 
From Dematteis (1989, 1994 and 2001), it is important to praise the concepts of territory and development, as well as the main factors of the latter. Studying issues such as the redistribution of population, counter-urbanization, displacement of activities and deconcentration, dispersion, scale, network debate and the dissemination of economic activities and individuals in the territory. There are reciprocal relationships among subjects in the global-network system with enhancement of local individuals and rooting, although it seems to be a contradictory aspect. There are articulated territorial local systems articulated in networks, formed by: local networks of individuals, where there are close and more distant relationships; the local milieu, understood as a set of local environmental conditions in which subjects operate collectively and historically; the relationship of the local network with the ecosystem, cognitively and materially; interactive relationships of the local network with extra-local networks at different scales: regional, national and global (Dematteis, 2001 and 2008; Saquet and Sposito, 2008).

From Raffestin (1993 [1980] and 2005), we highlight the power relations, usually present in social relationships; energy and information as basic components of work; the territorialities and the different networks and us; therefore, each society organizes its space combining these elements and, thus, produces its territory relationally and multidimensionally. The territory is historically formed from space by social relationships, made among the actors and between them and nature, organized with the contents of a territorial system. The actors make it possible to ensure cohesion of territories, control of people and things, according to their strategies, technologies and their interests.

In the territorial system, the tessituras, nodes and networks are subsets that support spatial practices, both economic and political and cultural practices, revealing the territorial production (Raffestin 1993 [1980]). At the same time, the actors work in order to achieve the maximum possible autonomy, there it is substantiated as a key benefit to the understanding of development, linking it to identity, to active territoriality (Dematteis, 2001) and governance, obviously, self-managed and self-governed.

And it seems to us that Magnaghi (2000, 2003, 2006a and 2006b) produces a didactically very well prepared synthesis on the territory and development issue, on a sustainable, local and autonomous perspective. Territory is built historically, between society and nature, and it is precisely this relationship that defines the concrete development meanings, degrading or sustainable. Thus, he also highlights the place consistently, the environmental dynamics and the preparation of development projects.

Sustainability, in the conception built over the years by Alberto Magnaghi, is reflected through territory, that is, it advocates in favor of political, economic, cultural and environmental sustainability, which has its synthesis in territorial sustainability. Its nature is there, together with the identity and other components of each site containing stays (cognitive materials and sediments) and ruptures (Table 1). So, in territory, there is a capacity for mobilization and self-management which needs to be well understood and valued along with nature, mutual aid, small businesses, autonomy, manual labor, popular knowledge, cooperation, heritage, biodiversity, etc., as we advocate in previous works (SAQUET, 2007, 2011a, 2011b, 2014b and 2014c).

In Brazil, the systematic discussion of the territory and development relationship is also more recent, so we highlight some works of authors who are emerging. Initially, we have 
noted some of Valdir Dallabrida's works for his career in the studies on the theme. In Dallabrida (2003), we verified the consistent attention to the methodology issue, which remains in production in subsequent years, as in his 2012 text, hereinafter mentioned. As it was not our purpose to make an exhaustive survey of his large production, due to our text theme, we chose another work, Dallabrida (2011a), by virtue of the qualified meeting in the same collection, of distinct authors' texts on development fundamental issues such as the political and administrative decentralization and different ways of their realization in Brazil and other Latin American countries, especially on the COREDES built over time in Rio Grande do Sul. Other current and relevant topics are also addressed, such as social participation, territorial development, management, covenants, scales and political actions. In Dallabrida (2011b), more precisely, the author highlights two perspectives of decentralization: one centered on the transfer of financial resources, for example, the federal units; another, in a broader sense, procedural and political, trying to increase social participation and even the distribution of power at the State level.

Table 1 - A summary focused on our operations in territorial development processes.

\begin{tabular}{|c|c|c|c|c|c|}
\hline & $\begin{array}{l}\text { G. Becattini } \\
\text { (Economist) }\end{array}$ & $\begin{array}{l}\text { A. Bagnasco } \\
\text { (Sociologist) }\end{array}$ & $\begin{array}{l}\text { G. Dematteis } \\
\text { (Geographer) }\end{array}$ & $\begin{array}{l}\text { C. Raffestin } \\
\text { (Geographer) }\end{array}$ & $\begin{array}{c}\text { A. Magnaghi } \\
\text { (Architect and } \\
\text { Urbanist) } \\
\end{array}$ \\
\hline Territory & $\begin{array}{l}\text { Is historically } \\
\text { built by } \\
\text { individuals, } \\
\text { networks, } \\
\text { technologies, } \\
\text { identities, } \\
\text { families, } \\
\text { schools, etc. }\end{array}$ & $\begin{array}{l}\text { Specific area, } \\
\text { with joints and } \\
\text { networks, } \\
\text { economic, } \\
\text { political and } \\
\text { cultural } \\
\text { specificities. }\end{array}$ & $\begin{array}{l}\text { Material reality, } \\
\text { modeled from the } \\
\text { environment by } \\
\text { social, economic, } \\
\text { political and } \\
\text { cultural forces; It } \\
\text { contains } \\
\text { networks, } \\
\text { ecosystems and } \\
\text { identities. }\end{array}$ & $\begin{array}{l}\text { Reality produced } \\
\text { from space } \\
\text { because of the } \\
\text { actors' } \\
\text { performance in } \\
\text { networks and } \\
\text { nodes, in the } \\
\text { form of } \\
\text { multidimensional } \\
\text { territorial } \\
\text { systems with } \\
\text { distinct } \\
\text { territorialities. }\end{array}$ & $\begin{array}{l}\text { Is produced in the } \\
\text { relationship } \\
\text { between society } \\
\text { and nature, at the } \\
\text { level of location, } \\
\text { with identities, } \\
\text { subjects and } \\
\text { nature. }\end{array}$ \\
\hline Development & $\begin{array}{l}\text { Social and } \\
\text { territorial } \\
\text { reality, singular, } \\
\text { local } \\
\text { empowerment, } \\
\text { with } \\
\text { concentration } \\
\text { and dispersion, } \\
\text { cooperation and } \\
\text { competition, } \\
\text { valuing } \\
\text { community. }\end{array}$ & $\begin{array}{l}\text { Social, } \\
\text { territorial, } \\
\text { plural, diffuse } \\
\text { and } \\
\text { heterogeneous, } \\
\text { with } \\
\text { reciprocity, } \\
\text { market, State } \\
\text { and political } \\
\text { parties. }\end{array}$ & $\begin{array}{l}\text { Corresponds to } \\
\text { self-organization } \\
\text { and self- } \\
\text { management } \\
\text { processes, } \\
\text { preserving the } \\
\text { environment and } \\
\text { culture. }\end{array}$ & $\begin{array}{l}\text { Is directly linked } \\
\text { to the } \\
\text { achievement of } \\
\text { autonomy and } \\
\text { the use of natural } \\
\text { resources. }\end{array}$ & $\begin{array}{l}\text { Means } \\
\text { coevolution with } \\
\text { preservation of } \\
\text { nature and culture } \\
\text { (territorial } \\
\text { sustainability), } \\
\text { autonomy and } \\
\text { self-management. }\end{array}$ \\
\hline
\end{tabular}

Mark Saquet's elaboration, 2015-16.

Moreover, we also realize the understanding of decentralization such as the construction of democracy, with decision-making autonomy and social inclusion, essential in the trend that we are working. This can happen in different scale levels, as shown by Cunha (2008) who, in his thought-provoking reflection on territorial development, highlights it at the 
regional level. According to Alexandre Cunha, territory has a multidimensional, historical and natural content, a result of the relationships between society and nature, thus it takes on different forms and extensions that need to be considered in each territorial development project: this needs to be focused on endogenous processes and social proximity relationships, without disregarding other scales, particularly the regional one.

Therefore, the territorial development issue, according to each space-time relationship, takes different scalar levels. It can be achieved at the level of municipalities, neighborhoods, rural communities, towns, etc., and this issue necessarily requires a process of management, monitoring and evaluation of activities, which needs to be done at the level of territorial governance, as highlighted below.

Therefore, from these considerations above, we note that different types and governance practices occur, as it is also revealed by Pires, Fuini, Mancini and Piccoli Neto (2011): informatively and lucidly, they present us with concrete interpretations of governance, modalities and some practices occurring in Brazil. After discoursing on the origins of the types of governance, they work, briefly, very important concepts, such as proximity, territory, actors, institutions, participation, etc., subsidizing the construction of development processes from the territorial governance, the book's focus. Thus, they facilitate our understanding of the different ways that governance assumes, and it can serve as a mediator for the institutionalization of a certain geographical indication because territorial governance corresponds to an organizational coordination among geographically close actors to solve problems, forwarding conciliations and constructing synergies with qualitative changes in the population's life (Fuini and Pires, 2015 [2009]). They are texts that must necessarily be in our readings, among the priorities of those who work with these themes (for governance detailing, see also Dallabrida, 2015).

Falcade (2011), in turn, helps us more specifically to think and understand the geographical indication processes, in a quality thesis and methodological consistency built from the concept of landscape understood as processuality and representation; therefore, critical to understand certain territory, its societal organization and the possibility to build or not a geographical indication. The conditions for this are accomplished historically, involving and being involved by a specific regulation which governs its establishment. However, the statement, as warned consistently by Ivanira Falcade, requires uniqueness and quality of the product, connection with certain territory, the organization of production and marketing, forming a certain region, issues also identified by Dallabrida (2012), for example. Thus, the landscapes studied by Falcade (2011), historically and regionally substantiated, there are symbols of the regions and wines which need to be understood, preserved and valued, features that also seem to meet with the synthesis prepared by Dallabrida (2012): the geographical indication requires brand identity products, different from those of other regions, which can constitute innovative ways for product protection, add value and assign credibility in the market.

As we can see, in this debate, albeit with partially distinct concepts, the development formatting is evident in regions historically constructed with certain specificities, without disregarding the formation of networks, sometimes competing, sometimes associative and/or cooperative and synergistic, as taught by the aforementioned Becattini (2000 [1979] and 2000 [1989]), Bagnasco (1977 and 1988), Dematteis (1989, 1994 and 2001), Raffestin (1993 [1980] and 2005) and Magnaghi (2000, 2003, 2006a and 2006b), among others. And this is an 
aspect that needs to be highlighted, along with the historical construction of the territorial conditions for the creation of certain geographical indication as the cultural identities regarded as heritage, nature and management of power relations. They are all elements and processes of territories in each space-time relationship.

In territory, there are internal and external relationships that form networks connecting individuals and places in trans-multi-scalar levels formed by nodes and networks of networks, which may take self-centered or hetero-centered forms (TURCO, 1988 and 2010; SAQUET and ALVES, 2015). They are trans-territorial networks, in the words of Camagni (1993 and 1997) and Rullani (2009). There are different scalar levels of territories and territorialities: individuals, families, properties, streets, neighborhoods, localities, cities, counties, regions, states, nations, continents, economic "blocks" and global relations. Territorialities, thus, define identities and differences in each territory (DEMATTEIS, 1999; SAQUET, 2007), in a kind of heritage territory, in the words of Bourdin (1984) or a territorial heritage (MAGNAGHI, 2000, 2003 and 2011) in close unity relationship with nature. Briefly, we believe that development processes, through the geographical indication or not, need to be guided and objectified with principles such as participation, cooperation, production of ecological food, environmental preservation, cultural development and preservation of each social group and territory, craftsmanship, solidarity, etc., as already mentioned.

\section{IDENTITY, HERITAGE AND GEOGRAPHICAL INDICATION}

Identity can be a powerful process of revitalization, renovation, preservation, political struggle and local development. It must be understood, explained, valued and it can be enhanced through dialogical participation in decision-making in territories, amid the inequalities and differences. The socially and historically constructed identity, as indicated by Gottmann (1947 and 1952), Dematteis (1994, 1995 and 2001) and Dematteis and Governa (2005), among others, can be an important mediator for resistance and the construction of locally-based development projects. We understand identity, as already socialized in Saquet (2007), Saquet and Galvão (2009) and Saquet and Briskievicz (2009), as a historical and relational product and condition for development in the direction signaled by Dematteis and Governa (2003) and Raffestin (2003).

Identity means dialectical unity in the terms indicated by Lefebvre (1995 [1969]), thus involving people and economic, cultural and political relationships without detachment of nature and territory. It contains, evidently, affective and belonging relationships, it may mediate the political organization from the differences and the common features among individuals with a view to projecting and (im)materialization of the present and future. Thus, in identity, there are heterogeneity, conflicts, differences, desires, needs, utopias and must occur necessarily mobilization initiatives and the struggle for social and territorial improvements, as praxis in a movement linked to an effective freedom (Dematteis, 1985). Identity, in this sense, is a component of the territorial heritage.

Heritage contains the elements and processes of each territory, being natural and social, material and immaterial. It is built socially and naturally; therefore, needs to be identified, understood, explained, represented, valued and enhanced culturally and politically. And then we are present, as directly connected bodies and dependent on our external nature (Marx, 1984), as beings

DRd - Desenvolvimento Regional em debate (ISSNe 2237-9029) 
who think, create, breathe, eat, sleep, walk, invent, degrade; so, they can revise daily practices when they do not meet the objectives of preserving culture and environment, when they do not meet our needs of experience reproducing solidarity and cooperation. There, they also assume centrality, our political organization, mobilization, our identities, our customs, knowledge, our water, plants, our animals and soil! We highlight the pronoun our because, if we understand the planet we live in collectively, we need to think and act for other thinking and not thinking beings, because we live related, interdependent on the same planet as the heritage of all mankind!

And one of the ways we have to preserve, even innovating, the territory we need so much every day is the identification, qualification and appreciation of typical products, with the institutionalization of geographical indications, as properly exposed by Falcade (2011), or in terms revealed by Denardin and Sulzbach (2010): a product with territorial identity incorporates all goods, services, information and specific images of certain territory, as in handicraft production of cassava flour in the coast of Paraná, for example, with unique flavor and differentiated texture, featuring an asset that involves services, information and representations. Thus, identity is one of the components of the territorial heritage, along with other economic, political and natural ones, which can guide the construction of certain geographical indication.

And, in an attempt to make the text more didactic, we developed a synthesis for such studies (Table 2), serving as guidance for both research and accomplishment of extension/cooperation projects focused on territorial development. To this end, we have been inspired by Marx (1985 and 2005), Marx and Engels (1991), Quaini (1974a and 2011), Dematteis (1964, 1985, 1995 and 2001), Raffestin (1977, 1993 [1980], 1984, 2003, 2005 and 2009), Santos (1996), Magnaghi (1976 and 2000), Indovina and Calabi (1974), Bagnasco (1977 and 1978), Turco (1988 and 2010), Thompson (1998), Rullani, Micelli and Di Maria (2000), Pecqueur and Zimmermann (2002), Hakmi and Zaoual (2008), Richez-Battesti (2008), Scoones (2009), Camagni (1990, 1993 and 1997), Saquet and Sposito (2008) and Saquet (2003 [2001], 2007, 2009, 2011a, 2011b, 2013, 2014b and 2014c).

A very important observation is the fact that this synthesis is not configured, in any way, as a model to be applied mathematically. There are different realities in Brazilian heterogeneity and other countries that need to be necessarily considered in each research process and/or operations in territorial development projects, either through the creation of a geographical indication, or through other initiatives. The levels and political organization intensities, for example, vary from region to region, from country to country, as well as soil types, climates, knowledge, etc. This synthesis is also composed of suggestions derived from our trajectory in teaching, research and university extension, which must be adjusted to each research and cooperation project for development.

As it is fairly well known, in the capitalist mode of production, there are characteristics inherent to life in society as tensions, conflicts, territorial disputes, subordination to capital agents and state regulations, substantiating what Martins (1973) and Bagnasco (1999) call as local society. Cooperation relationships and, concurrently, class relationships, technical and technological innovations, innovations in daily practices that need to be considered along with the identities, are accomplished.

And this social process that takes place in space-time relationship territorializes, deterritorializes and reterritorializes $(T D R)$, at the same historical period or among different periods in the same place or different places. This territorial process, as stated by Raffestin (1993 [1980], 1984 and 2005) and Turco (1988 and 2010) and as mentioned in own works (Saquet, 2003 [2001], 2007, 2009, 2011b, 2013 and 2015), it can be used to study the transformation processes (discontinuity) and/or permanences (continuities) in time and space. Thus, our following 
considerations need to be appropriate to each space-time relationship and adjusted to each research project (objectives and goals, schedule and ideological and political choice) and/or extension/cooperation focused on development, as we did on this occasion, highlighting the rural characteristics and, at the same time, recognizing other aspects dialectically related to development: the country side and city relationships, nature, people, groups and social classes, the different mediations historically achieved, territorial practices, cultures, networks and, of course, the territories.

Table 2 - A synthesis attempt - territorialities and temporalities in the TDR process at the same space at different times.

\begin{tabular}{|c|c|c|c|}
\hline & TERRITORIALIZATION & DETERRITORIALIZATION & RETERRITORIALIZATION \\
\hline & $\begin{array}{l}\text { MAIN FEATURES AND } \\
\text { LIMITS }\end{array}$ & $\begin{array}{c}\text { MAIN FACTORS AND } \\
\text { IMPACTS }\end{array}$ & MAIN POSSIBILITIES \\
\hline $\begin{array}{l}\text { Inorganic } \\
\text { nature }\end{array}$ & $\begin{array}{l}\text { - Water, soil, vegetation } \\
\text { cover, geomorphology, } \\
\text { climate. }\end{array}$ & $\begin{array}{l}\text { - Concentrated, degrading } \\
\text { and polluting } \\
\text { transformations. } \\
\text { - Preserved areas, etc. }\end{array}$ & $\begin{array}{l}\text { - Needs to be identified, } \\
\text { discussed and defined in each } \\
\text { territory and territory network, } \\
\text { from its singularities for crops, } \\
\text { creations and transformations. }\end{array}$ \\
\hline $\begin{array}{l}\text { Subjects, } \\
\text { relationships } \\
\text { and classes }\end{array}$ & $\begin{array}{l}\text { - Classes and social groups, } \\
\text { objectives, goals, rhythms } \\
\text { and needs. } \\
\text { - Local and regional } \\
\text { commands, disputes and } \\
\text { conflicts. } \\
\text { - Relations of trust and } \\
\text { reciprocity. } \\
\text { - Organizations and } \\
\text { mobilizations. } \\
\text { - Economic initiatives. } \\
\text { - Customs and identities. } \\
\text { - Know-how and } \\
\text { craftsmanship. } \\
\text { - Ecological food production. } \\
\text { - Preservative initiatives, etc. }\end{array}$ & $\begin{array}{l}\text { - Buildings (especially with } \\
\text { heritage meaning), } \\
\text { agreements, covenants, } \\
\text { coalitions, political, } \\
\text { recreational and cultural } \\
\text { associations. } \\
\text { - Agrochemical crops. } \\
\text { - Technological innovations, } \\
\text { financing, subordination, etc. } \\
\text { - Different insertions in the } \\
\text { market. } \\
\text { - Accelerated life rhythms. }\end{array}$ & $\begin{array}{l}\text { - Need to be identified, } \\
\text { discussed and defined in each } \\
\text { territory and territory network: } \\
\text { economic, political, cultural } \\
\text { and environmental, according } \\
\text { to the specificities of families, } \\
\text { groups and classes, valuing } \\
\text { slow and solidary rhythms. }\end{array}$ \\
\hline $\begin{array}{l}\text { (Im)material } \\
\text { mediators }\end{array}$ & $\begin{array}{l}\text { - State: federal, state and } \\
\text { municipal. } \\
\text { - Private and public } \\
\text { companies. } \\
\text { - Techniques and } \\
\text { technologies. } \\
\text { - Knowledge, popular } \\
\text { knowledge and science. } \\
\text { - Technical assistance. } \\
\text { - Associations. } \\
\text { - NGOs. } \\
\text { - Unions. } \\
\text { - Workforce. } \\
\text { - Social movements. }\end{array}$ & $\begin{array}{l}\text { - Buildings, existing and } \\
\text { projected projects, levels of } \\
\text { water, soil and subsoil } \\
\text { contamination (where } \\
\text { applicable), forms of } \\
\text { disposal of liquid and solid } \\
\text { waste, distribution of land } \\
\text { and other common goods, } \\
\text { public spaces, performance } \\
\text { quality and gains already } \\
\text { achieved. } \\
\text { - Management mechanisms } \\
\text { and public policies, etc. }\end{array}$ & $\begin{array}{l}\text { - Need to be identified, } \\
\text { discussed and defined in each } \\
\text { territory and territory network: } \\
\text { economic, political, cultural } \\
\text { and environmental, valuing } \\
\text { democracy, social participation, } \\
\text { autonomy, reciprocity, self- } \\
\text { management and self- } \\
\text { organization. } \\
\text { - The state must fulfill its } \\
\text { constitutional and social roles. }\end{array}$ \\
\hline $\begin{array}{l}\text { (Im)material } \\
\text { Spatio- } \\
\text { temporal } \\
\text { practices }\end{array}$ & $\begin{array}{l}\text { - Distinct temporary and } \\
\text { more effective allocations. } \\
\text { - Properties, domains, } \\
\text { installment payments, } \\
\text { delimitations, demarcations. } \\
\text { - Different life rhythms, etc. }\end{array}$ & $\begin{array}{l}\text { - Land concentration and } \\
\text { other means of production. } \\
\text { - Concentrated, degrading } \\
\text { and polluting } \\
\text { transformations. } \\
\text { - Expropriation of workers }\end{array}$ & $\begin{array}{l}\text { - Need to be identified, } \\
\text { discussed and defined in each } \\
\text { territory and territory network: } \\
\text { economic, political, cultural } \\
\text { and environmental, with a view } \\
\text { to the desired development, }\end{array}$ \\
\hline
\end{tabular}

DRd - Desenvolvimento Regional em debate (ISSNe 2237-9029)

v. 6, n. 1, p. 4-21, jan./jul. 2016. 


\begin{tabular}{|c|c|c|c|}
\hline & & $\begin{array}{l}\text { and owners. } \\
\text { - Popular, associative, } \\
\text { cooperative and solidary } \\
\text { organizations of struggle and } \\
\text { resistance to capital and the } \\
\text { bourgeois state. } \\
\text { - Accelerated production and } \\
\text { life rhythms, etc. }\end{array}$ & $\begin{array}{l}\text { valuing the slow and solidary } \\
\text { rhythms. }\end{array}$ \\
\hline $\begin{array}{l}\text { Cultural } \\
\text { identities } \\
\text { and } \\
\text { reference } \\
\text { territories }\end{array}$ & $\begin{array}{l}\text { - Fragile and strong ties with } \\
\text { the place and territory: } \\
\text { anchoring/rooting. } \\
\text { - Belonging, affection and } \\
\text { recognition. } \\
\text { - Mobilization, resistance } \\
\text { and political struggle. } \\
\text { - Historical heritage } \\
\text { (buildings, know-how, } \\
\text { identity, languages, rites, } \\
\text { customs, etc.). } \\
\text { - Peasant culture with the } \\
\text { incorporation of other } \\
\text { behaviors and values: } \\
\text { cooperation, solidarity and } \\
\text { market coexistence. }\end{array}$ & $\begin{array}{l}\text { - Changes/disruptions and } \\
\text { dissolutions. } \\
\text { - Fragile ties with the } \\
\text { production place and daily } \\
\text { life. } \\
\text { - Advances of standardized } \\
\text { consumption. } \\
\text { - Advances already achieved } \\
\text { politically and culturally, i.e., } \\
\text { with typical products, etc. }\end{array}$ & $\begin{array}{l}\text { - Continuities/permanencies. } \\
\text { - Resistance and struggle. } \\
\text { - Strong territorial ties: } \\
\text { anchoring /rooting. } \\
\text { - Reproduction of peasant } \\
\text { culture with the incorporation } \\
\text { of other behaviors and values: } \\
\text { cooperation, solidarity and } \\
\text { market coexistence. } \\
\text { - Identity renewal, etc. }\end{array}$ \\
\hline $\begin{array}{l}\text { Local and } \\
\text { extra local } \\
\text { networks, } \\
\text { and nodes } \\
\text { (in different } \\
\text { scales) }\end{array}$ & $\begin{array}{l}\text { - Asymmetries and conflicts. } \\
\text { - Spatial Continuities. } \\
\text { - With tendency of the } \\
\text { national hetero-centered } \\
\text { networks. } \\
\text { - With tendency of local } \\
\text { and/or regional self-centered } \\
\text { networks. } \\
\text { - Solidary marketing: local } \\
\text { and/or regional market. } \\
\text { - Synergies and reciprocity: } \\
\text { cooperation, solidarity, } \\
\text { associations to produce, } \\
\text { marketing, celebration, at } \\
\text { last, in order to live, etc. }\end{array}$ & $\begin{array}{l}\text { - Limits/boundaries } \\
\text { transposition, discontinuities/ } \\
\text { disruptions. } \\
\text { - Dissemination and fluidity. } \\
\text { - With tendency of domestic } \\
\text { and international hetero- } \\
\text { centered networks. } \\
\text { - Dispersion and articulation. } \\
\text { - Local and/or regional } \\
\text { initiatives, etc. }\end{array}$ & $\begin{array}{l}\text { - New spatial continuities. } \\
\text { - With tendency of local and/or } \\
\text { regional self-centered } \\
\text { networks. } \\
\text { - Synergies and reciprocity: } \\
\text { cooperation, solidarity, } \\
\text { associations, etc. }\end{array}$ \\
\hline
\end{tabular}

Marcos Saquet's elaboration, 2015-16.

This is a didactic proposal, nothing more than that, to contribute to the discussion of the topic, especially trying to clarify the importance of the territory and development in a pluralistic conception focused on environmental preservation, autonomy, cultural appreciation, in short, under the terms marked here. The theoretical and conceptual issue is essential and has also been the subject of our academic and popular work, through a concept focused on territorial development of a local basis, in a practice of cooperation with the subjects of each territory (Dansero, 2008; Dansero and Zobel, 2007; Saquet, 2011b and 2014b; Saquet, Dansero and Candiotto, 2012).

Thus, understanding the cultural, natural, economic and political processes is essential, in time and space, identifying and understanding the cultural heritage (Martins, 1973) or the cultural roots of the peasant world (Quaini, 2011), e.g., together with the other characteristics of each ecosystem. Procedural culture that involves values, meanings, conflicts, common 
customs and innovations, in short, social relationships and daily practices (Thompson, 1998). It is transmitted, from generation to generation, knowledge, values, principles, techniques and standards; continuities and economic, political, cultural and natural and fundamental changes coexist in the study and in the execution of the geographical indication as a possible mechanism to build a territorial development participatively.

\section{FINAL CONSIDERATIONS}

The territory-development relationship, therefore, can take different paths, privileging cultural, natural and political processes, as now we have pointed out, with local, participative, preservative basis, amplitude facilitated precisely by the polysemy of the territory concept and its (im)material singularities. From the latter, multiple possibilities for development can be set up, such as through the institutionalization of a certain geographical indication.

The studies for the geographical indication implementation need to be consistent, plural-dimensional (Dansero and Zobel, 2007), historical and interdisciplinary, and its consummation must contain, necessarily, social participation, decision-making autonomy and self-management, preservation of our external and social nature, appreciation of our culture, the enhancement of the specific conditions of each ecosystem, the relationships of solidarity and trust, social and spatial proximity (community relationships) and sustainable possibilities. This must take place through a continuous, educative, cooperative and co-participatory work among individuals of the local society, involving, of course, Universities and other associative institutions and NGOs working with the people, as well taught by Paulo Freire, as recently outlined in Saquet (2015) as well as indicated by Fuini and Pires (2015 [2009]): the local actors are potential for development.

Thus, our theoretical considerations need to be used to research and guide our daily practice focused on territorial development, with our direct involvement with the subjects of each project and process. It is also necessary to produce better knowledge for basic education in a territorial approach like this we are showing; generate specific and more qualified methods for scientific and interdisciplinary research considering the spatial and temporal singularities and, finally, qualifying a little more the methodologies we have to work with people in a participatory conception of local development of ecological and cultural basis. We believe that in this text, we socialize some important support to these future tasks that can be combined with others already published in Saquet (2011a, 2011b, 2012, 2013 and 2014b) and Saquet, Dansero and Candiotto (2012).

It is imperative to rebuild corporate and territorial processes with alternative paths that, for us, happen through the formation of a class and place consciousness (Harvey, 1982; Magnaghi 2000, 2009 and 2011; Lussault, 2009; Quaini, 2010), assuming the meaning of territorial struggle awareness and a more communitarian, solidary and cultural life with a qualified policy. The aspiration to social justice, supplying people's needs, along with the appreciation of man as a political individual is an essential premise, and it is understood in a praxis in favor of autonomy and social transformation (Marx and Engels, 1991; Freire, 2011 [1974] and 2011 [1996]). 
And this conception focused on cooperation and territorial development is essential, because we believe in a process of identity renewal (Rullani, Micelli and Di Maria, 2000), within the peasant culture (Thompson, 1998) and the power fields (Raffestin 1993 [1980]), that combines customs and changes from the references of each territory, centered in what is called the territorial sharing made through the complexity government with autonomy (Rullani, Micelli and Di Maria, 2000; Magnaghi, 2000) and nature conservation. The societynature coevolution, in these terms, present in territories, with identities, differences, inequalities and nature, must be understood as humanity's heritage (Magnaghi, 2000, 2006a and 2006b; Dematteis, 2007); therefore, it should be self-governing with social and environmental responsibility.

Acknowledgments: We thank $\mathrm{CNPq}$ for the financial support and granting the productivity scholarship and also the Araucaria Foundation for the financial support intended for our project entitled Agricultura camponesa (agro)ecológica: temporalidades $e$ territorialidades.

\section{BIBLIOGRAPHY}

ANDRADE, Manuel Correia de. Geografia, região e desenvolvimento. São Paulo: Brasiliense, 1971 [1967].

BAGNASCO, Arnaldo. Tre Italie. La problematica territoriale dello sviluppo italiano. Bologna: Il Mulino, 1977.

BAGNASCO, Arnaldo. Problematiche dello sviluppo e articolazione dell'analisi: un paradigma per l'analisi territoriale. In: BAGNASCO, A.; MESSORI, M. e TRIGILIA, C. (Org.). Le problematiche dello sviluppo italiano. Milão: Feltrinelli, 1978. p. 205-251.

BAGNASCO, Arnaldo. La costruzione sociale del mercato. Studi sullo sviluppo di piccola impresa in Italia. Bologna: Il Mulino, 1988.

BAGNASCO, Arnaldo. Tracce di comunità. Bologna: Il Mulino, 1999.

BECATTINI, Giacomo. Dal 'setore' industriale al 'distretto' industriale. Alcune considerazioni sull'unità di indagine dell'economia industriale. In: BECATTINI, G. (Org.). Il distretto industriale. Torino: Rosenberg \& Sellier, 2000 [1979]. p. 41-56.

BECATTINI, Giacomo. Il distretto industriale marshalliano come concetto socio-economico. In: BECATTINI, G. (Org.). Il distretto industriale. Torino: Rosenberg \& Sellier, 2000 [1989].

BECKER, Bertha. O uso político do território: questões a partir de uma visão do terceiro mundo. In: BECKER, B. et al (Org.). Abordagens políticas da espacialidade. Rio de Janeiro: UFRJ/Departamento de Geociências, PPG, 1983. p. 1-21.

BOURDIN, Alain. Le patrimoine reinventè. Paris: PUF, 1984. 
CAMAGNI, Roberto. Strutture urbane gerarchiche e reticolare: verso una teorizazzione. In: CURTI, F. e DIAPPI, L. (Org.). Gerarchie e reti di città: tendenze e politiche. Milão: Franco Angeli, 1990.

CAMAGNI, Roberto. Le reti di città in Lombardia: introduzione e sintesi della ricerca. In: CAMAGNI, R. e DE BLASIO, G. (Org.). Le reti di città. Teoria, politiche e analisi nell'area padana. Milão: Franco Angeli, 1993. p. 21-52.

CAMAGNI, Roberto. Luoghi e reti nelle politiche di competitività territoriale. In:

CAMAGNI, R. e CAPELLO, R. (Org.). Strategie di competitività territoriale: il paradigma a rete. Torino: SEAT, 1997. p. 167-179.

CUNHA, Alexandre. Desenvolvimento territorial: algumas reflexões teórico-conceituais derivadas de estudo monográfico. In: ALVES, A.; CARRIJO, B.; CANDIOTTO, L. (Org.). Desenvolvimento territorial e agroecologia. São Paulo: Expressão Popular, 2008. p. 47-61.

DALLABRIDA, Valdir. Governança territorial: um primeiro passo na construção de uma proposta teórico-metodológica, Desenvolvimento em questão, Ijuí, v. 1, n. 2, 2003, p. 73-98.

DALLABRIDA, Valdir (Org.). Governança territorial e desenvolvimento. Rio de Janeiro: Garamond, 2011a.

DALLABRIDA, Valdir. Concepções teóricas que sustentam o debate sobre descentralização político-administrativa. In: DALLABRIDA, Valdir (Org.). Governança territorial e desenvolvimento. Rio de Janeiro: Garamond, 2011b. p. 40-52.

DALLABRIDA, Valdir. Território e desenvolvimento sustentável: indicação geográfica da erva-mate de ervais nativos no Brasil, Informe GEPEC, Toledo, vol. 16, n. 1, 2012, p. 42-59.

DALLABRIDA, Valdir. Governança territorial: do debate teórico à avaliação da sua prática, Análise Social, n. 215, Lisboa, p. 304-328, 2015.

DANSERO, Egidio. Geografia e cooperazione allo sviluppo. Prospettive di ricerca. In: BIGNANTE, E.; DANSERO, E.; SCARPOCCHI, C. (Org.). Geografia e cooperazione allo sviluppo. Temi e prospettive per un approccio territoriale. Milão: Franco Angeli, 2008. p. 926.

DANSERO, E.; ZOBEL, B. Verso un dialogo tra comunità scientifica e comunità locale. In: Promozione della sostenibilità nel Pinerolese - un percorso di ricerca/azione territoriale. Turim: Euro Mountains, 2007. p. 135-141.

DELEUZE, G.; GUATTARI, F. O anti-édipo. Capitalismo e esquizofrenia. Rio de Janeiro: Imago Editora, 1976 [1972].

DEMATTEIS, Giuseppe. Alcuni relazioni tra l'ambito territoriale dei rapporti sociali e i caratteri della casa rurale, Atti 19 ${ }^{\circ}$ Congresso Geografico Italiano, Como, v. 3, 1964, p. 239-253.

DEMATTEIS, Giuseppe. "Rivoluzione quantitativa" e nuova geografia, Laboratorio di Geografia Economica, n. 5, Università degli Studi di Torino, Torino, 1970.

DEMATTEIS, Giuseppe. Le metafore della terra. La geografia umana tra mito e scienza. Milano: Feltrinelli, 1985. 
DEMATTEIS, Giuseppe. Contingenza ambientale e ordine econômico, lo sviluppo locale in una prospettiva geografica. In: BECATTINI, G. (Org.). Modelli locali di sviluppo. Bologna: Il Mulino, 1989. p.131-147.

DEMATTEIS, Giuseppe. Possibilità e limiti dello sviluppo locale, Sviluppo locale, I, 1, Firenze, 1994, p. 10-30.

DEMATTEIS, Giuseppe. Progetto implicito. Il contributo della geografia umana alle scienze del territorio. Milano: Angeli, 1995.

DEMATTEIS, Giuseppe. Sul crocevia della territorialità urbana. In: DEMATTEIS, G. et al. (Org.). I futuri della città - Tesi a confronto. Milano: Angeli, 1999. p. 117-128.

DEMATTEIS, Giuseppe. Per uma geografia della territorialità attiva e dei valori territoriali. In: BONORA, Paola. (Org.). Slot, quaderno 1. Bologna: Baskerville, 2001. p. 11-30.

DEMATTEIS, Giuseppe. Per una geografia dell'agire collettivo. In: BORGARELLO, G.; DANSERO, E.; DEMATTEIS, G.; GOVERNA, F.; ZOBEL, B. (Org.). Promozione della sostenibilità nel Pinerolese: un percorso di ricerca/azione territoriale. Turim: Euro Mountains, 2007. p. 27-31.

DEMATTEIS, Giuseppe. Sistema Local Territorial (SLOT): um instrumento para representar, ler e transformar o território. In: ALVES, A.; CARRIJO, B.; CANDIOTTO, L. (Org.).

Desenvolvimento territorial e agroecologia. São Paulo: Expressão Popular, 2008. p. 33-46.

DEMATTEIS, G.; GOVERNA, F. Ha ancora senso parlare di identità territoriale? Atti dei Convegni Lincei, 194 - Convegno internazionale: La nuova cultura delle città. Roma: Accademia Nazionale dei Lincei, 2003. p. 264-281.

DEMATTEIS, G.; GOVERNA, F. Il territorio nello sviluppo locale. Il contributo del modelo Slot. In: DEMATTEIS, G.; GOVERNA, F. (Org.). Territorialità, sviluppo locale, sostenibilità: il modello Slot. Milano: Angeli, 2005. p. 15-38.

DENARDIN, V.; SULZBACH, M. Produtos com identidade territorial: o caso da farinha de mandioca no Litoral Paranaense. In: SAQUET, M; SANTOS, R. (Org.). Geografia agrária, território e desenvolvimento. São Paulo: Expressão Popular, 2010. p. 219-235.

FALCADE, Ivanira. A paisagem como representação espacial. A paisagem vitícola como símbolo das indicações de procedência de vinhos no Rio Grande do Sul. Tese (Doutorado em Geografia), Porto Alegre, UFRGS, 2011.

FREIRE, Paulo. Pedagogia do oprimido. São Paulo: Paz e Terra, 2011 [1974].

FREIRE, Paulo. Pedagogia da autonomia. Saberes necessários à prática educativa. São Paulo: Paz e Terra, 2011 [1996].

FUINI, Lucas. Território e geografia no Brasil: uma revisão bibliográfica, Revista Formação, Presidente Prudente, n. 21, vol. 1, 2014, p. 3-20.

FUINI, L. e PIRES, E. As dimensões da governança territorial. In: SAQUET, M. e SPOSITO, E. (Org.). Territórios e territorialidades: teorias, processos e conflitos. Rio de Janeiro: Consequência, 2015 [2009]. p. 289-312.

GOLDENSTEIN, L. e SEABRA, M. Divisão territorial do trabalho e nova regionalização, Revista do Departamento de Geografia, n. 1, USP, 1982, p. 21-47. 
GOTTMANN, Jean. De la méthode d'analyse en géographie humaine, Bulletin de la Societé de Géographie, Paris, n. 301, 1947, p. 1-12.

GOTTMANN, Jean. La politique des États et leur Géographie. Paris: Armand Colin, 1952.

GOTTMANN, Jean. The significance of territory. Charlottesville: University Press of Virginia, 1973.

HAKMI, L. e ZAOUAL, H. La dimension territoriale de l'innovation. In: ZAOUAL, H. (Org.). Développement durable des territoires. Paris: L’Harmattan, 2008. p.31-60.

HARVEY, David. O trabalho, o capital e o conflito de classes em torno do ambiente construído nas sociedades capitalistas avançadas, Espaço e Debates, ano 2, n. 6, São Paulo, 1982, p. 6-35.

HEIDRICH, Álvaro. Espaço e multiterritorialidade entre territórios: reflexões sobre a abordagem territorial. In: PEREIRA, S.; COSTA, B.; SOUZA, E. (Org.). Teorias e práticas territoriais: análises espaço-temporais. São Paulo: Expressão Popular, 2010. p. 25-35.

INDOVINA, F.; CALABI, D. Sull'uso capitalistico del territorio. In: LUSSO, G. (Org.). Economia e territorio. Milano: Angeli, 1974. p. 205-222.

LEFEBVRE, Henri. Lógica formal. Lógica dialética. Rio de Janeiro: Civilização Brasileira,1995 [1969].

LUSSAULT, Michel. De la lutte des classes à la lutte de places. Paris: Grasset, 2009.

MAGNAGHI, Alberto. Il territorio nella crisi, Quaderni del territorio - ristrutturazione produttiva e nuova geografia della forza-lavoro, anno I, n.1. Milano: CELUC Libri, 1976. p. $15-29$.

MAGNAGHI, Alberto. Il progetto locale. Torino: Bollati Boringhieri, 2000.

MAGNAGHI, Alberto. La rappresentazione identitaria del patrimonio territoriale. In:

DEMATTEIS, G. e FERLAINO, F. (Org.). Il mondo e i luoghi: geografie delle identità e del cambiamento. Torino: IRES/SGI, 2003. p. 13-20.

MAGNAGHI, Alberto. Gli atlanti del patrimonio e lo 'statuto dei luoghi' per uno sviluppo locale autosostenibile. In: BERTONCIN, M. e PASE, A. (Org.). Il territorio non è un asino. Voci di attori deboli. Milão: Franco Angeli, 2006a. p. 23-51.

MAGNAGHI, Alberto. Dalla partecipazione all'autogoverno della comunità locale: verso il federalismo municipale solidade, Democrazia e Diritto, n. 3, 2006b, p. 1-13.

MAGNAGHI, Alberto. Territorio: dal progetto implícito al progetto esplicito. In: Le frontiere della Geografia. Novara-Torino: UTET, 2009. p. 275-292.

MAGNAGHI, Alberto. Educare al territorio: conoscere, rappresentare, curare, governare. In: GIORDA, C. ; PUTTILLI, M. (Org.). Educare al territorio, educare il territorio Geografia per la formazione. Roma: Carocci, 2011. p. 32-42.

MARTINS, José de S. A imigração e a crise do Brasil agrário. São Paulo: Pioneira, 1973. MARX, Karl. Manuscritos: economia y filosofia. Madrid: Alianza Editorial, 1984. 
MARX, Karl. GRUNDRISSE - Lineamientos fundamentales para la crítica de la economia política. 1857/58 (Vol. I e II). Trad. de Wenceslao Roces. México, D.F.: Fondo de Cultura Econômica, 1985.

MARX, Karl. Il capitale (I, II e III). Roma: Newton Compton Ed., 2005.

MARX, K. ; ENGELS, F. A ideologia alemã (Feuerbach). SP: Hucitec, 1991.

PECQUEUR, B.; ZIMMERMANN, J. Les fondementsd'une économie de proximités, Marseille, GREQAM, DT 02A26, 2002, p. 1-23.

PIRES, E.; FUINI, L.; MANCINI, R. e PICCOLI NETO, D. Governança territorial: conceito, fatos e modalidades. Rio Claro, SP: UNESP - IGCE; PPGG, 2011.

QUAINI, Massimo. Per la storia del paesaggio agrario in Liguria. Note di geografia storica sulle strutture agrarie della Liguria medievale e moderna. Savona: C.C.I.A.A., 1973.

QUAINI, Massimo. Storia, geografia e territorio. Sulla natura, gli scopi e i metodi della geografia storica, Miscellanea storica Ligure, 6, 7, 1974a.

QUAINI, Massimo. Marxismo e geografia. Firenze: La Nuova Italia, 1974b.

QUAINI, Massimo. Dalla coscienza di classe alla "coscienza di luogo" ovvero "de la lutte des classes à la lutte des places". Declinazioni del concetto di luogo e di paesaggio, Fondazione Benetton, Treviso, 2010, p. 1-13.

QUAINI, Massimo. Geografia: pensamento impensado (Aos colegas e companheiros geógrafos do grande Brasil). In: SAQUET, M.; SUZUKI, J. e MARAFON, G. (Org.). Territorialidades e diversidade nos campos e nas cidades latino-americanas e francesas. São Paulo: Expressão Popular, 2011. p.15-25.

RAFFESTIN, Claude. Paysage et territorialitè, Cahiers de géographie du Québec, vol. 21, n.53-54, 1977, p. 123-134.

RAFFESTIN, Claude. Territorializzazione, deterritorializzazione, riterritorializzazione e informazione. In: TURCO, A. (Org.). Regione e regionalizzazione. Milano: Angeli, 1984. p. 69-82.

RAFFESTIN, Claude. Por uma geografia do Poder. São Paulo: Ática, 1993 [1980].

RAFFESTIN, Claude. Immagini e identità territoriali. In: DEMATTEIS, G. e FERLAINO, F. Il mondo e i luoghi: geografie delle identità e del cambiamento. Torino: IRES, 2003. p. 3-11.

RAFFESTIN, Claude. Dalla nostalgia del territorio al desiderio di paesaggio. Elementi per una teoria del paesaggio. Firenze: Alinea, 2005.

RAFFESTIN, Claude. A produção das estruturas territoriais e sua representação. In: SAQUET, M. e SPOSITO, E. (Org.). Territórios e territorialidades: teorias, processos e conflitos. São Paulo: Expressão Popular, 2009. p. 17-35.

RICHEZ-BATTESTI, Nadine. Innovations sociales et dynamiques territoriales. Un aproche par la proximité. In: ZAOUAL, H. (Org.). Développement durable des territoires. Paris: L'Harmattan, 2008. p. 61-87.

RULLANI, Enzo. La città al tempo delle reti. In: Le frontiere della Geografia. NovaraTorino: UTET, 2009. p. 145-172. 
RULLANI, E.; MICELLI, S.; DI MARIA, E. Tra città reale e città virtuale: il territorio nel postfordismo. In: RULLANI, E.; MICELLI, S. e DI MARIA, E. (Org.). Città e cultura nell'economia delle reti. Bologna: Mulino, 2000. p.13-56.

SANTOS, Milton. Metamorfoses do espaço habitado. São Paulo: Hucitec, 1988.

SANTOS, Milton. A natureza do espaço. Técnica e tempo. Razão e emoção. São Paulo: Hucitec, 1996.

SAQUET, Marcos. Os tempos e os territórios da colonização italiana. Porto Alegre: EST Edições, 2003 [2001].

SAQUET, Marcos. O território: diferentes interpretações na literatura italiana. In: SPOSITO, E.; SAQUET, M.; RIBAS, A. (Org.). Território e desenvolvimento: diferentes abordagens. Francisco Beltrão/PR: UNIOESTE, 2004. p.121-147.

SAQUET, Marcos. Entender a produção do espaço geográfico para compreender o território. In: SPOSITO, E. (Org.). Produção do espaço e redefinições regionais: a construção de uma temática. Presidente Prudente/SP: FCT/UNESP/GAsPERR, 2005. p. 35-51.

SAQUET, Marcos. Abordagens e concepções de território. São Paulo: Expressão Popular, 2007.

SAQUET, Marcos. Por uma abordagem territorial. In: SAQUET, M. e SPOSITO, E. (Org.). Territórios e territorialidades: teorias, processos e conflitos. São Paulo: Expressão Popular, 2009. p. 73-94.

SAQUET, Marcos. Contribuições teórico-metodológicas para uma abordagem territorial multidimensional em geografia agrária. In: SAQUET, M.; SUZUKI, J.; MARAFON, G. (Org.). Territorialidades e diversidade nos campos e nas cidades latino-americanas e francesas. São Paulo: Expressão Popular, 2011a. p. 209-226.

SAQUET, Marcos. Por uma geografia das territorialidades e das temporalidades. Uma concepção multidimensional voltada para a cooperação e para o desenvolvimento territorial. São Paulo: Outras Expressões, 2011b.

SAQUET, Marcos. Il territorio della geografia. Milano: Franco Angeli, 2012.

SAQUET, Marcos. Por uma abordagem territorial: continuando a reflexão. In: SAQUET, Marcos. (Org.). Estudos territoriais na ciência geográfica. São Paulo: Outras Expressões, 2013. p. 47-74.

SAQUET, Marcos. Territorialidades, relações campo-cidade e ruralidades em processos de transformação territorial e autonomia, Revista Campo-Território, Uberlândia, v. 9, n. 18, 2014a, p. 1-30.

SAQUET, Marcos. Participação social em territórios de identidade e desenvolvimento numa práxis dialógica e cooperada. In: SILVA, Onildo; SANTOS, Edinusia; COELHO Neto, Agripino. (Org.). Identidade, território e resistência. Rio de Janeiro: Consequência, 2014b. p. 11-36.

SAQUET, Marcos. Dinâmicas territoriais rurais e urbanas. In: CASTRO, C.; BERNAT, I.; SILVA, Q.; SODRÉ, R. (Org.). Territórios, paisagens e suas dinâmicas. São Luís (MA): Editora UEMA, 2014c. p. 65-92. 
SAQUET, Marcos. Uma perspectiva para a abordagem da questão agrária no Paraná e atuação em projetos de desenvolvimento territorial de base local. In: ROSAS, Celbo. (Org.).

Perspectivas da geografia agrária no Paraná - abordagens e enfoques metodológicos. Ponta Grossa: Estúdio Texto, 2015. p. 11-23.

SAQUET, M.; ALVES, A. Desarrollo territorial heterocentrado y autocentrado: diferentes formas de movilizar saberes y redes en Brasil, Revista Textual, Chapingo - México, n. 65, 2015, p. 11-34.

SAQUET, M.; BRISKIEVICZ, M. Territorialidade e identidade: um patrimônio no desenvolvimento territorial, Caderno Prudentino de Geografia, v.1, n. 31, Presidente Prudente (SP), 2009, p. 3 - 16.

SAQUET, M.; DANSERO, E.; CANDIOTTO, L. (Org.). Geografia da e para a cooperação ao desenvolvimento territorial: experiências brasileiras e italianas. São Paulo: Outras Expressões, 2012.

SAQUET, M.; GALVÃO, A. A valorização territorial e multidimensional do patrimônio de Francisco Beltrão (PR), Campo-Território, v. 4, n. 8, Uberlândia, 2009, p. 98-120.

SAQUET, M.; SPOSITO, E. Território, territorialidade e desenvolvimento: diferentes perspectivas no nível internacional e no Brasil. In: CANDIOTTO, L.; ALVES, A.; CARRIJO, B. (Org.). Desenvolvimento territorial e agroecologia. São Paulo: Expressão Popular, 2008. p. $15-31$.

SCOONES, Ian. Livelihoods perspectives and rural development, The Journal of Peasant Studies, v. 36, n. 1, 2009, p. 171-196.

THOMPSON, Edward. Costumes em comum: estudos sobre a cultura popular tradicional. São Paulo: Cia das Letras, 1998.

TOLEDO, Víctor; BARRERA-BASSOLS, Narciso. A memória biocultural. São Paulo: Expressão Popular/AS-PTA, 2015 [2008].

TURCO, Angelo. Verso uma teoria geografica della complessità. Milano: Unicopli, 1988.

TURCO, Angelo. Configurazioni della territorialità. Milão: Franco Angeli, 2010.

Artigo recebido em: 01/04/2016

Artigo aprovado em: 08/04/2016 